\title{
State of Information Technology Auditing in Botswana
}

\author{
Nugi Nkwe \\ Dept. of Accounting and Finance, University of Botswana \\ Private Bag UB00701, Gaborone, Botswana \\ Tel: 267-355-4065Ｅ-mail: nugi.nkwe@mopipi.ub.bw
}

Received: August 19, 2011 Accepted: November 24, 2011 Published: December 1, 2011

doi:10.5296/ajfa.v3i1.894 URL: http://dx.doi.org/10.5296/ajfa.v3i1.894

\begin{abstract}
This article summaries the state of Information Technology Auditing in Botswana. It looks at the adoption rate of IT and challenges and successes of IT auditing and How IT has changed Auditing in Botswana.

A number of developing countries are adopting Information Technology (IT) and this is happening at fast pace but problems which are coupled with it are not fully addressed. One of the areas which are still lagging behind is Information Technology Auditing. A lot of researchers have found that Information Technology is the best technology to have come to this world but it has brought certain ills with it. To try and curb these ills, Information Technology Auditing is a major area to be considered. Botswana has to act quickly and adopt Information Technology.
\end{abstract}

Keywords: Accounting, Information Technology, Information Technology Auditing, Botswana 


\section{Introduction}

Many companies the world over are aware of the benefits of information technology auditing which results in efficiency and profitability. Botswana is in line with other countries who have embraced information communications technology (ICT) and Information technology auditing (IT auditing) is emerging lately due to the embracement of ICT. The government of Botswana has invested and still to invest more in ICT infrastructure. The government intentions are captured clearly in the VISION 2016, through its pillar "educated and Informed society". ICT has had a radical impact on businesses and governments; governments are going the e-government route, banking sector is adopting internet banking and mobile banking and universities are going the e-learning route. All this new developments need to be closely managed and controls which are fit to each have to be identified and be in place.

Different organizations and industries face different ICT problems. Institutions such as Botswana Information Technology Society (BITS), Institute of Auditors Botswana (IIA), Botswana Institute of Accountants and others are starting to brainstorm solutions to curb emerging problems brought by ICT. From accountants perspective ICT has brought new ways of going through a transaction which does not only involve figures, sometimes it goes way into technology and most of the time the accountants are lost on the way. From technology point of view, emerging technologies have made it even more complex for IT personnel to keep track of their assets and resources. Measuring performance and efficiency of IT assets and resources is gradually approaching zero. Crime perpetrated using computers is on the rise and IT personnel need to make sure their instruments work well and to the best interest of the business and not aliens.

In today's business environment, technology is critical to the smooth running and operations of any company. For that reason, KPMG (2009) believes that IT audit is an essential component of overall audit activity. All too often, however, audit departments operate in 'silos' where IT audit is undertaken in isolation from other audit activity and, indeed, other IT assurance activity. For a wholly independent and impartial view, we believe that IT audit should be delivered as part of an audit, involving the wider audit team and, where appropriate, other specialists .In the current information society, ICT and Auditing are intertwined or heavy coupled. The intertwine of the two is brought by the fact that IT is responsible for designing, implementing and maintaining many controls over an organization's business processes .IT has a critical role in collecting, processing and sorting data that is summarized and reported in financial statements (Canon and Crowe, 2004, p.31). ("New Developments in Auditing”2010) pointed out that the government of Botswana is faced with a mammoth task of increasing information technology and accountants personnel who are currently labeled as scarce skills. The two disciplines are essential for IT auditing maturity more especially in the current turbulent times.

\section{Accountancy and Auditing in Botswana}

Auditing is one of the oldest professions in the world, as put by Richard Brown (1905, quoted in Mautz \&Sharaf, 1961) as follows: 
"The origin of auditing goes back to times scarcely less remote than that of Accounting... Whenever the advance of civilization brought about the necessity of one man being intrusted to some extent with the property of another, the advisability of some kind of check upon the fidelity of the former would become apparent."

For all these years, auditing is forced to adapt to the changing environment within the accounting sphere.IIA (2010) found some of the changes as follows:

• $\quad$ 1999: “Bull Market” and Y2K

- 2001: Terrorism, BCP, and disaster recovery

- $\quad$ 2002: Enron, WorldCom, and financial scandals

- 2002-2003: Sarbanes-Oxley and PCAOB

- 2004-2007: SOX, SOX, and SOX

- 2008: Implosion of the economy

- 2009: Economic crisis; realignment of coverage

Botswana too recognize the need to have auditors, the president of IIA-Botswana Lesetedi Lesetedi has said that internal auditors compromise a critical component of good governance essential for efficient operations and internal control of an organization. Chief Internal Auditor at BURS said integral audits determine the information reliability, compliance, assets security, economic prudence and well defined goals within organization (The Voice, 2007). In Botswana, accountants act was formulated in 1988(BIA Report 2009).Auditing cannot be traced far back but since its adoption it has grown tremendously. Mr Duncan Majinda, CEO of BIA on his interview (Mmegi, 2010) stated that Botswana will implement two acts; Accountants Act and Financial Reporting Act. Accountants Act (revised) had to be reviewed due to the fact that it had become archaic and out of line with modern running of the profession while the Financial Reporting Act (new)establishes a Botswana Accounting Authority Oversight as the umbrella body of the profession, it will be the regulator of the profession .

The former Minister of Finance, Mr Gaolatlhe in his speech(2008) said, Ministry in conjunction with the Institute of Internal Auditors (IIA) Botswana has fully embraced His Excellency the President, Lt. General Seretse Khama Ian Khama's principles referred to as the 4D s, namely Democracy, Development, Dignity and Discipline. As democracy is an important cornerstone of good governance and prudent economic management, so is Internal Audit as it is one of the four pillars of good corporate governance. Therefore Internal Audit would want to see affairs of corporate entities run in a democratic and transparent manner where there are consultations with all stakeholders.

Auditing firms and the government undertake different types of audits e.g._Statutory Audit Nonstatutory Audit, External Audit, Internal audit, Final Audit, social audit, performance Audit, even though the frequency is dependent on each. 


\section{Information Technology in Botswana}

Information Technology (IT) can be defined as phrase that covers all forms of technology that are used to create, store and distribute information in all its formats, mostly using computers.”According to NDCC 54.59.01 Information technology means the use of hardware, software, services and supporting infrastructure to manage and deliver information using voice, data and video".

Diffusion of IT in Botswana is growing at a fast rate and this is captured clearly by Mutula \& Jain(2001),

In recognition of the opportunities and challenges occasioned by IT, member states of the Southern African Development Community (SADC) in 1999 identified areas that needed to be addressed for the region to realize an information society. Among key areas identified were: improving and broadening equitable access to information and communications technology (ICT); reducing costs related to IT; developing an SADC-wide infrastructure; encouraging the growth of software and hardware development facilities; and improving human resource capacity. The importance of policies related to national information and communication infrastructures a favorable regulatory environment, the liberalization of the telecommunication sector and the strengthening of the education sector was also emphasized (SADC Secretariat, 1999)

Botswana has set measures to increase diffusion of IT. Some of the strategies adopted by the government are National ICT Policy -Vision 2016, National ICT Policy -Ministry Charter and others.

\subsection{National ICT Policy-Vision 2016}

The vision 2016 is a policy that is aimed at trying to bring Botswana to an information society. The policy is advocating for availability of ICT equipment, access to ICT resources (telephones, radio and TV services) and others.

There is a dedicated policy within Vision 2016, addressing IT and this is Information Technology Policy which is detailed in National Development Plan (NDP9).

\subsection{National ICT Policy-Ministry Charter}

The government through its ministries has spent and continues to spend on technology. The government is embracing technology as an efficiency tool ( Iyanda \& Ojo,2008).The ministry charter is tasked with enhancement of research ,science and technology and improve the quality of and access to mass media services in Botswana. According to Botswana Government, 2004 P1.3bn (US\$200m) was allocated for technology programs in the NDP 9 through several ministries. In 2004, the ministry's budget was P144million (Budget Speech 2003).

\subsection{ICT Adoption and Usage}

Most businesses use the Internet primarily for collaboration purposes (Sairosse \& Mutula, 2004). The government is the biggest consumer of ICT and government use of IT is 
particularly visible through the central government site and use of ICT in the control of national income and expenditure sources (Uzoka \& Ndzinge, 2009)

The rankings of e-readiness survey have become an established benchmark for countries seeking to harness the information system's potential to drive business efficiency, improve the provision of public services and encourage the integration of local economies with the global economy (Lane et al., 2004). Botswana was ranked 3rd in the Networked Readiness Index (NRI) in Africa in 2003 and 2004. Globally, Botswana ranked 55 in 2003 and 50 in 2004 (Bitz et al., 2006). However, the 2008 ranking places Botswana in the 5th position among African countries and 78th position globally (The Economist Intelligence Unit Limited, 2008).

\section{Impact of IT on Auditing}

Technologies such as electronic data interchange (EDI), image processing, and electronic file transfer (EFT) will make traditional audit trails disappear. These technologies will greatly change the nature of the audit process, which traditionally has relied on source documents in paper form. To audit on-line systems, auditors will have to incorporate on-line audit software as their primary audit tool and gather evidence electronically. The use of such technology will free the auditor from many mundane audit tasks and allow the auditor to use this time for higher level tasks, such as understanding the client's business and assessing various risks (Bierstaker, Burnaby \& Thibodeau, 2001).University of Botswana and other institutions which produce accounting and Information systems students are faced with a great challenge of producing students who can cope with the ever changing accounting, auditing and technology landscape.

\section{Information Technology Auditing}

Information Technology Auditing (IT auditing) began as Electronic Data Process (EDP) Auditing and developed largely as a result of the rise in technology in accounting systems, the need for IT control, and the impact of computers on the ability to perform attestation services. The last few years have been an exciting time in the world of IT auditing as a result of the accounting scandals and increased regulation. IT auditing has had a relatively short yet rich history when compared to auditing as a whole and remains an ever changing field (Wikipedia encyclopedia)

According to Wasik (1991) and Christy (1995), CAIS or Information Technology (IT)- based accounting systems are more easily manipulated fraudulently than manual accounting systems especially in advanced systems. Businesses in Botswana have introduced a couple of IT-based systems and they depend a lot on them. This is a great risk, IT auditing in Botswana is still at its infancy stage. Big auditing firms in Botswana like KPMG, Enerst \& Young and Deloitte are still working hard to establish IT auditing departments in their firms. The Institute of Internal Auditors Botswana, are also looking at the situation, Mr Maboane ,IIAB Public Affairs officer stated that the institute is looking for ways to improve the adoption of IT auditing in Botswana. Currently the adoption is at a worrisome pace. The situation is not only lacking on the industry side even academically there is not enough research on the area 
of IT Auditing in Botswana.

IS audit's relationship to financial auditing has been described as changing from being a "fly on the back of a giant gorilla" ten years ago, to "driving” the audit today, to "taking over" the audit within the next five years (Bagranoff \& Vendrzyk,2000).Botswana too, is suppose to move in the same direction as other countries and adopt IT auditing.

\section{Drivers}

Auditing is one of the areas that are highly dynamic. The environment and other factors dictate the way auditing is carried out. Hinson (2007) stated that there are four main areas which drive IT auditing; political, economic, social and technical aspects.

\section{Political}

Although accounting laws have mandated audits of corporate finances by independent, qualified auditors for many years, we are gradually witnessing the introduction of laws and regulations requiring auditors to review computer systems, information processing, and other aspects such as corporate governance, health and safety, and so on. Professional standards are being documented and recommended for computer and other auditors by ISACA, IIA, AICPA, and similar organizations.

\section{Social}

There are many professional groups of IT auditors, collectively comprising a relatively supportive and close-knit community within the wider worlds of audit, risk/security management, and governance. "Bridging" or interpreting between the IT and business worlds has been an important role for IT auditors, given the number of business people with limited IT expertise and vice versa. Thankfully, this is becoming less of an issue as IT knowledge spreads into the wider business and IT people are increasingly taking business/management qualifications.

\section{Economic}

As the development and implementation of IT has progressed incessantly since the 1940/50s, information processing has become absolutely essential to most modern organizations, hence risks to information assets are more important than ever. Stakeholders and managers are looking to assess and manage their information risks and so are turning to specialist IT auditors for their independent, competent assessment of IT-related risks.

\section{Technical}

The advance of IT and telecommunications technologies creates a never-ending stream of issues of concern to IT auditors, while at the same time it is a source of new tools and techniques to do our jobs more effectively. The Internet is a good example: eBusiness and Internet connectivity substantially changes the organization's information security challenges, and provides IT auditors with access to a global knowledge base on auditing, technology, risk, control, security, governance, and every other topic imaginable. 
There is growth in the use of IT in different sectors: Individual, business access and government access. The growth in adoption of IT is major stimulus for adoption of IT auditing. Individuals are accessing internet a lot these days, visiting sites such as facebook and other social networksites. Businesses are moving towards e-business. Business to business transactions is predominantly online such as orders and payments. Government is adopting new forms of availing services to the public. The services are mostly computer based.

\subsection{E-Government:}

Botswana is investing heavily on e-government. There is an increasing interest in the use of e-services by the public. The government has a website which provides a lot of information on different aspects of Botswana; on the website one can download the requirements and application forms for visa without being in physical contact with the Department of Immigration. Major projects to facilitate e-government are under construction within several government's ministries and departments. For example:

Department of Town and Regional Planning (DTRP), has spent over P 30Million to date on the development of planning portal (Ditogamaano 2008). The portal was to necessitate digital planning of the country. $\mathrm{T}$ he public can have information at the figure tips availed by the portal .Information such as trends in change of use, allocations and others will be readily available.

National ID System: Botswana was the first in the SADC region to develop a national ID system with Automatic Fingerprints Identification System (AFIS).The card called "Omang” (High Tech Security Solutions, August 1999).

E-Passport: The introduction of the new passport with new technologically advanced features is one way of the government to try and bring Botswana up to par with other countries. The features found in the new passport will allow the department of Immigration to be effective and efficient. The goal is to have a linkage with other government's department s.

E-license: Motor vehicle license is another area the government is trying to improve. The public used to have a lot of grievances regarding the old paper passed licensing system. The problems spanned areas such as replacements and others. With the aid of computers, replacements and renewals are a piece of cake.

The intention is to have the three; passport, license and identity card link together to avoid capturing data at different sources. As Hammer (1990) stated that capturing data at multiple sources may result in redundancy and multiple versions of the truth. The government's e-governance intentions are clear thus the same should be extended to IT auditing. All the above efforts will results in crimes such as identity thefts and others, IT auditing is unavoidable as part of e-government's initiatives.

There are a lot of e-government initiatives which are ongoing such as Tribal Land Management Systems and State Land Management System under the Ministry of Lands and Housing. 


\subsection{E-Health}

The government has started to partner with developed countries to get assistance on e-health. Projects on e-health require a lot of financial and human capital investments. In 2008 the government of India and Botswana went into partnership which resulted in Botswana receiving sophisticated e-health machines from India. The machines will enable doctors in India to consult and diagnose patients in Botswana without having to travel (BOPA 2008).With the current issues affecting health sector, audits cannot be left out of the health industry.

\subsection{E- Education}

A lot of efforts have been channeled towards e-learning. There is a national e-learning committee tasked with formulating and promotion of e-learning in Botswana. The ministry of education is trying to encourage its partners to look at e-learning as one of the possible teaching modes in Botswana.The university of Botswana just completed a strategy on digital scholarship which focuses on embracing digital scholarship. The university went further and is working on strategy for e-learning which will be a great driver in the area of e-learning. There are a number of institutions which have adopted e-learning, for example BOCODOL, NIIT and others.

\subsection{E-Business}

Internet access and web presence are growing rapidly in Botswana and this say the same about commercial sites across banks, tour companies, insurance firms, airlines and others. Most businesses are providing their employees with internet and email access at their desks, homes and mobile devices.

A lot of e-business in Botswana involves the banking industry. Majority of banks in Botswana see e-business as an opportunity and competitive edge.FNB in Botswana was the first to launch mobile and internet banking and banks such as Barclays followed(Monitor 2010).Banks generally offer the following e-services; electronic fund transfer(EFT),electronic banking (EBK),automatic bank teller (ATM) and others.

Other businesses too, have adopted e-business. Businesses the world over are practicing different forms of e-business like electronic data interchange(EDI),electronic advertising, electronic consulting, electronic mail, electronic research, electronic conferencing, computerized inventory system(CIS) ,electronic order processing(EOP) and others. There is also a lot of international trade due to globalization thus a lot of online transactions.

\section{Challenges}

IT auditing is faced with many challenges, such as human capital, policy, education and others. The starting point is who is to do IT audit? The public expects finance auditors to undertake IT audit. Certified Public Accountants are increasingly being asked to solve information technology problems for clients and prospective clients, according to the 2010 Top Technology Initiatives Survey by the American Institute of Certified Public Accountants. Even within the audit profession, the challenge is huge as to who owns IT auditing and line of 
management. IT and Finance auditors each feel they should own the new specialism of auditing. The line of management is another burning issue, Finance managers feel the reporting should be with them while IT managers feel otherwise. Both groups overwhelmingly agree that IS audit is becoming more important. However, financial auditors describe the current and future relationship between the two practices differently. Financial auditors are more likely to indicate that the financial audit will continue to dominate the IS audit. IS auditors see a growing IS dominance over the financial audit (Vendrzyk \&Bagranoff, 2003). During the past decade, IS audit has changed from being a small support piece of the financial audit to being a driving force in the overall public audit (Bagranoff \& Vendrzyk, 2000).

Since IT auditing is new in Botswana and elsewhere in Africa, there is still a vacuum in terms of professional and tertiary education. There are professional courses such as CISA and CISM which are common and available at different learning institutions but in Botswana the opposite is true thus a major challenge. Tertiary institutions in Botswana do not have a well structured programme, at certificate or degree level or even a specialization in IT auditing.

IT auditing as area of research is still an untapped in Botswana. This is another challenge; there is no literature either scholarly or otherwise on this topic. This is a major setback contributing to the slow growth of this discipline.

Areas of specialization such as Purchasing and Supply, CCNA, MCSE and others were quick to break into the market but IT auditing is still struggling. Companies are still reluctant or have not been convinced by IT auditing. The low level of adoption is seen somehow with students too. Students, however, were ambivalent in their opinions concerning two aspects of a career in auditing. These were reflected in their responses to statements concerning whether or not they would like the life beyond the job and the perceived time and effort needed to prepare for an occupation in this field( Yavas \& Arsan,1996).

Technology assumes the role of a double sided sword when dealing with issues of IT auditing, challenge and driver. IT auditing involves a lot of technology as enabler. There are many technologies used for finance and IT auditing, and they keep changing. It is a challenge for IT auditor to keep up with the changing technology.

The other challenge faced by IT auditing is perception. "When we start an audit they look so unhappy to see us. Hey, we are doing our job as internal auditors; the other teams do not have any right to treat us badly" said by Ravi an internal audit manager. Auditors are perceived as opinionated, argumentative, autocratic, bureaucratic, insensitive, callous, political, critical, impolite, or bully. Unfortunately, IT auditors are painted with the same brush thus a challenge for them.

\section{Successes}

The success of auditing in Botswana is still to be documented .This is due to the fact that IT auditing is a new discipline. Most of the success can be traced to the benefits, most companies are enjoying the benefits of good IT auditing such as a good system which is a product of well planned and audited system. Companies across the world have done a lot of 
IT audits and these have helped them to exist.

A number of banks in Botswana have managed to identify fraudulent activities and dealt with them accordingly.FNB have put controls in place and in use to mitigate the risks associated with online services and these have worked.(FNB Website)

Stanbic Bank too has upped its game, they have introduced mastercard securecode as control to improve security, and this was a result of through IT auditing.(Stanbic website)

Botswana Police PR officer Christopher Mbulawa said that the police service works with Interpol on matters of cross-border crime. "Where something may be going on that we do not yet know of, Interpol are our eyes internationally. They contact us in cases where criminals are involved in international schemes”. Botswana through Interpol they have managed to do audits and identify and investigate certain crimes perpetrated using computers (Mmegi, 2010).

Internationally too, I T auditing has been successful: The founder of Indian outsourcing giant Satyam appeared in court in a billion-dollar corporate fraud case dubbed "India's Enron. As a result of auditing it was found that in January 2009 he had falsified profits plunging the Indian business world into turmoil (Hyderabad, India (AFP 2010)).

\section{Implications}

IT auditing adoption is an indication of some form of readiness of a business or country to take part in global trade. From the point of view of IT and business ,the importance of global trade needs to be emphasized.The rapid growth of IT has forced a lot of countries to attain some measure of IT Auditing. Countries look at IT auditing as away and enabler of global trade, where all businesses regardless of geographical location can share and utilize information. Adoption of IT auditing will educate the business community on how IT audit can add value to an organization.

Botswana as a developing country, the government and community appreciate IT and this has brought problems. IT audits if done well, will identify, and assess design of controls and then test the effectiveness of the controls .A company or country that has attained a certain level on fore-mentioned areas will be better placed to carry out business with less risk. Audits are needed for assurance and internal controls. As organizations make huge investments in technology, IT auditing can provide the assurance that huge losses are not just around the corner.

Organisations in Botswana are to benefit a lot from IT audits. When planned and executed based on best practices will cover risks associated with confidentiality, integrity and availability of information technology infrastructure and resources. There are also risks related to the effectiveness, efficiency and reliability of IT (Computers and Technology 2010).Most companies in Botswana still miss the fact that IT risk is business risk. Threats and vulnerabilities in IT operations can directly affect an entire organization.

With the recent cases involving fraud and cyber crime, international organizations and governments are looking at ways to curb these ills. There are standards, regulations and 
policies governing the way companies do business. For companies to trade, they have to meet regulatory or compliance requirements before they can trade. Scandals such as the Enron's, AIG and others have driven the surfacing of IT auditing. Nowadays a lot of US and international requirements such as Sarbanes Oxley are gaining ground. IT auditors provide the assurance that such requirements are met.

One area that is neglected is communication. Communication can break or make a company. IT auditing facilitates communication between business and technology management. As auditors carry out their procedures, such as observing, interviewing and testing result in valuable information in written reports and oral presentations and managers can pick a lot of information from there (Computers and Technology 2010). The reverse communication from senior management to the technology professionals is also critical.

IT auditing is major tool for IT governance. The objectives of IT governance which are IT is aligned with the business, IT enables the business and maximizes benefits, IT resources are used responsibly, IT risks are managed appropriately. IT auditors are involved in getting assurance that each of these objectives is realized.

\section{The way forward}

AUDITING IN GENERAL HAS RECEIVED MIXED REVIEWS in light of last year's series of corporate failures. Although internal auditors have not been specifically implicated in any of the recent financial-reporting incidents, these events have nonetheless put somewhat of a damper on our reputation in the minds of clients and the general public. And, although more and more people are beginning to appreciate the value of internal auditing in helping to prevent future Enrons and maintain good governance, the profession could still benefit from -- and is perhaps long overdue for -- an image makeover. (Williams, 2003)

The government has a major role in enabling environment for IT auditing adoption in Botswana. The policies of the country must be in line with the new challenges such as cybercrimes and others. Unless laws advocate for IT auditing, this important area will be unnoticed .The government ministries and departments should be seen as leaders in adoption of IT auditing.

Management support is critical especially for projects requiring considered amount of budget and affecting some operational processes(Vasarhelyi and Kuenkaikaew, 2009)Adoptions such as technology, BPR Projects and auditing need top management support .For IT auditing to be adopted and have impact on the business, top management should support the initiative. If there is no support, IT auditing will be viewed as an enemy by the organization. Companies and government top management should come to the party and play a role. It is also necessary that the auditor has access to the systems and data of each auditee (Handscombe 2007). Such access requires management approval.

Major issue to be addressed is the employee skill set. IT auditing adoption is slow because of not at par skills of employees. This new specialization needs certain skills or combination of two or more existing skills. Employees are finding it tough to adapt and training is highly needed. The current crop is made of two extremes: general/finance auditors and IT guys. For 
easy IT auditing adoption, employees who have business and IT skills are needed.

Private sector too should assist the government. IT auditing if not done well or not at all can haunt the organization for several years. Private sector should take part in adoption of IT auditing. The sector can educate and improve employee skill sets. Solo efforts by the government will not make enough impact.

Professional (BIA, IIA and others) and learning institutions should do the cultivating role, they should produce students who are capable to handle the demands of IT auditing. Universities should review their curriculums to accommodate the new specialism. Programmes such as Business Information Systems offered by the University of Botswana should have options for students to pursue IT auditing as a specialization. Professional institutions should encourage their members to take professional courses which are tailored to IT auditing such as CISA qualifications.

\section{Conclusions}

The adoption level of IT auditing across the world and in Botswana is encouraging. Few companies have adopted this new specialization, they have put policies and frameworks but there are still not enough. For areas like auditing, companies have to go all out to make sure they adopt IT auditing in full and not just certain parts. Big auditing companies in Botswana, like Ernest and Young, KPMG and others have recently set new units which will be responsible for IT auditing. Majority of these units are small and without experienced personnel, this impact negatively on the growth of IT auditing. Auditing companies must seriously consider IT auditing and allocate it enough resources such as experts in the area and technology resources. The Institute of Internal Auditors should change some of its policies and frameworks to reflect the new field. There should be advocacy for adoption of IT Auditing by professional bodies

\section{References}

Bagranoff, N., Vendrzyk, V. (2000). The changing role of IS audit among the big five accounting firms, Information Systems Control Journal, 5 .33-7.

Bierstaker, J, Burnaby, P, \& Thibodeau, J. (2001). The impact of information technology on the audit process: an assessment of the state of the art and implications for the future, $\begin{array}{llllll}\text { Managerial Auditing } & \text { Journal, } & 16(3), & 159 & - & 164 .\end{array}$ http://dx.doi.org/10.1108/02686900110385489

Botswana Institute of Accountants Report 2009, Changing environment within the Accounting sphere, June 2010

Cannon, D. M. \& Crowe, G.A. (2004). SOA Compliance: Will IT Sabotage Your Efforts?, The Journal of Corporate Accounting and Finance, 15(5), 31 - 37. http://dx.doi.org/10.1002/jcaf.20035

Daily News. (2008, August 14). India Botswana Partnership, p.4

Daily News. (2008, June 3). Internal auditors Allies, p.4 
Daily News. (2008, May 10).Internal Auditors Essential for economic growth, p.3

Economist. (2004, November 18). The Future of Auditing, Called to Account, p12

Hammer, M. (1990, July-August). Reengineering Work: Don't Automate, Obliterate, Harvard Business Review, pp. 104-112.

Hinson, G.(2007). The State of IT Auditing in 2007, EDPACS: The EDP Audit, Control, and Security Newsletter, 36(1), 13 - 31. http://dx.doi.org/10.1080/07366980701547065

Iyanda ,O \& Ojo, S. (2008). Motivation, influences, and perceived effect of ICT adoption in Botswana organizations, International Journal of Emerging Markets, 3(3), 311 - 322. http://dx.doi.org/10.1108/17468800810883710

Jain,S \& Mutula, S.(2001). Diffusing Information Technology in Botswana: a framework for vision 2016, Information Development, 17(4), 234-241. http://dx.doi.org/10.1177/0266666014241042

Lee, T.H \& Azham M. A. (2008). Audit challenges in Malaysia, Accountants Today, p24-26 Mmegi. (2010, June 17). New developments in auditing, p5

Sairosse, T. \& Mutula, S.M. (2003). Economic impact of the Internet: study of cyber cafes in Gaborone Botswana,Library Hitech, 21(4) ,451-62

The Monitor. (2010, June 15). FNB launches e-wallet, p.B.2

The Voice. (2008, May 10). IIA walk the talk, p.8

Uzoka, F.-M. E. and T. Ndzinge. (2009). Empirical analysis of biometric technology adoption and acceptance in Botswana. Journal of Systems and Software 82(9): 1550-1564. http://dx.doi.org/10.1016/j.jss.2009.04.041

Vasarhelyi, M. and S. Kuenkaikaew. (2009c). Continuous Auditing and Continuous Control Monitoring: Case studies from leading organizations. Working paper, Rutgers Accounting Research Center, Rutgers Business School

Vendrzyk, V. P., and Bagranoff, N.A. (2003). The evolving role of IS audit: A field study comparing the perceptions of IS and financial auditors. Advances in Accounting 20: 141-163. http://dx.doi.org/10.1016/S0882-6110(03)20007-9

Williams P. (2003).Association for integrity in accounting enters the discussion of accounting reforms. The CPA Journal, 73(4), 14

Yavas, U, \& Arsan,N. (1996). Image of auditing as a field of study and a career among college students, Managerial Auditing Journal, 11(5), 41 - 44. http://dx.doi.org/10.1108/02686909610120523

\section{Copyright Disclaimer}

Copyright reserved by the author(s).

This article is an open-access article distributed under the terms and conditions of the Creative Commons Attribution license (http://creativecommons.org/licenses/by/3.0/). 